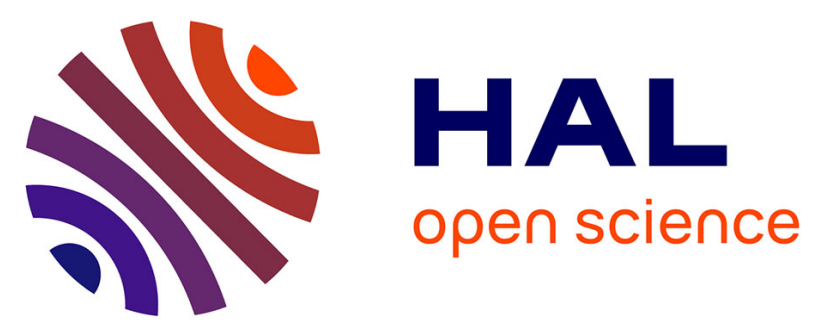

\title{
Calcium channels, external calcium concentration and cell proliferation
}

\author{
Anne-Sophie Borowiec, Gabriel Bidaux, Natascha Pigat, Vincent Goffin, \\ Sophie Bernichtein, Thierry Capiod
}

\section{To cite this version:}

Anne-Sophie Borowiec, Gabriel Bidaux, Natascha Pigat, Vincent Goffin, Sophie Bernichtein, et al.. Calcium channels, external calcium concentration and cell proliferation. European Journal of Pharmacology, 2014, 739, pp.19-25. 10.1016/j.ejphar.2013.10.072 . hal-03060345

\section{HAL Id: hal-03060345 \\ https://hal.science/hal-03060345}

Submitted on 13 Dec 2020

HAL is a multi-disciplinary open access archive for the deposit and dissemination of scientific research documents, whether they are published or not. The documents may come from teaching and research institutions in France or abroad, or from public or private research centers.
L'archive ouverte pluridisciplinaire HAL, est destinée au dépôt et à la diffusion de documents scientifiques de niveau recherche, publiés ou non, émanant des établissements d'enseignement et de recherche français ou étrangers, des laboratoires publics ou privés.

\section{()ㅜ) $\Theta$}

Distributed under a Creative Commons Attribution - NoDerivatives| 4.0 International 


\title{
Calcium channels, external calcium concentration and cell proliferation
}

\author{
Anne-Sophie Borowiec ${ }^{\mathrm{a}}$, Gabriel Bidaux ${ }^{\mathrm{a}}$, Natascha Pigat ${ }^{\mathrm{b}}$, Vincent Goffin ${ }^{\mathrm{b}}$, \\ Sophie Bernichtein ${ }^{\mathrm{b}}$, Thierry Capiod ${ }^{\mathrm{b}, *}$ \\ a INSERM U1003, LabEx ICST, Université Lille 1, Villeneuve d'Ascq F-59655, France \\ ${ }^{\mathrm{b}}$ INSERM U845, Research Center Growth and Signalling Research Center, Paris Descartes University, Sorbonne Paris Cité, Faculty of Medicine, Bâtiment, \\ Leriche, 96 rue Didot, Paris F-75993, France
}

\section{A R T I C L E I N F O}

Article history:

Received 5 July 2013

Received in revised form

28 September 2013

Accepted 17 October 2013

\section{Keywords:}

Calcium channels

Cell cycle

Cell proliferation

Calcium sensing receptor

\begin{abstract}
A B S T R A C T
Evidence for a role for calcium channel proteins in cell proliferation is numerous suggesting that calcium influx is essential in this physiological process. Several studies in the past thirty years have demonstrated that calcium channel expression levels are determinant in cell proliferation. Voltage-gated, storeoperated, second messengers and receptor-operated calcium channels have been associated to cell proliferation. However, the relationship between calcium influx and cell proliferation can be uncoupled in transformed and cancer cells, resulting in an external calcium-independent proliferation. Thus, protein expression could be more important than channel function to trigger cell proliferation suggesting that additional channel functions may be responsible to reconcile calcium channel expression and cell proliferation. When needed, external calcium concentration is obviously important for calcium channel function but it also regulates calcium sensing receptor (CaSR) activity. CaSR can up- or down-regulate cell proliferation depending on physiological conditions. CaSR sensitivity to external calcium is within the 0.5 to $5 \mathrm{mM}$ range and therefore, the role of these receptors in cell proliferation must be taken into account. We therefore suggest here that cell proliferation rates could depend on the relative balance between calcium influx and CaSR activation.
\end{abstract}

(c) 2013 Published by Elsevier B.V.

\section{Contents}

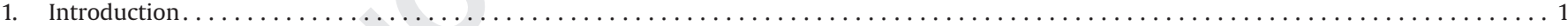

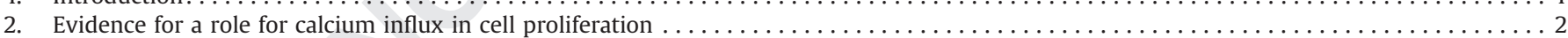

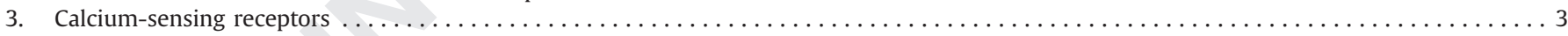

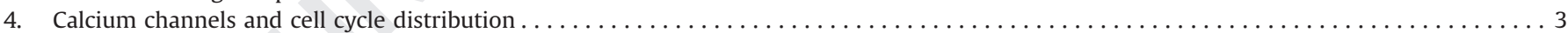

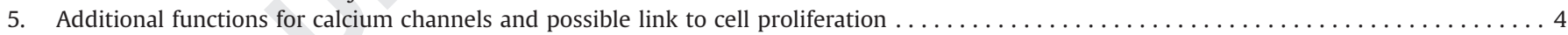

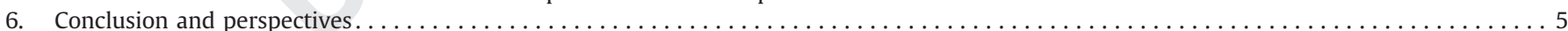

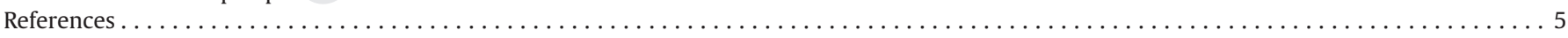

\section{Introduction}

The relation between external $\mathrm{Ca}^{2+}$ concentration and cell proliferation is not as straightforward as originally thought in mammalian cells. First, several cell lines can proliferate even when external $\mathrm{Ca}^{2+}$ is reduced to a few tens of $\mu \mathrm{M}$ (Capiod, 2013). Second, when external $\mathrm{Ca}^{2+}$ is required, we need to clarify whether proliferation rate increase results from the activation of plasma membrane calcium channels or calcium-sensing receptors (CaSR) that are also present in many cell

\footnotetext{
* Corresponding author. Tel.: +331726063 71; fax: +33172606401.

E-mail address: thierry.capiod@inserm.fr (T. Capiod).
}

types (Riccardi and Gamba, 1999). CaSR are G-protein coupled receptors (GPCR) (Brown et al., 1998) and intracellular $\mathrm{Ca}^{2+}$ transients were recorded (Breitwieser and Gama, 2001; Rey et al., 2010) following activation by increasing external $\mathrm{Ca}^{2+}$ concentrations in the $0.5-5 \mathrm{mM}$ range. Variations in cytosolic calcium $\left[\mathrm{Ca}^{2+}\right]_{\text {cyt }}$ transient frequency have been proposed as being responsible for cellular responses modulation. Indeed, cytosolic calcium transients are dependent on external calcium in the long term suggesting the need for $\mathrm{Ca}^{2+}$ influx for their maintenance (Putney and Bird, 2008; Shuttleworth and Mignen, 2003). However, recent evidence against a role for calcium influx in $\left[\mathrm{Ca}^{2+}\right]_{\text {cyt }}$ oscillations came from experiments performed in the presence of siRNA against ORAI1 or ORAI3. $\left[\mathrm{Ca}^{2+}\right]_{\text {cyt }}$ oscillations were recorded even in ORAI1 (Wedel et al., 2007) and 

33 34 35 36 37 38 38 39 40 41 42 43 44 45 46 47 48 48 50 50 51 52 53 54 54 55 56 57 58 59 60 61 62 63 64 65 66
ORAI3 (Thompson and Shuttleworth, 2011) knock-downs suggesting that neither $I_{\text {CRAC }}$ (calcium release activated calcium current) or $I_{\text {arc }}$ (arachidonic related calcium current), the archetype currents for storeoperated (SOCE) and store-independent calcium (SICE) entries respectively, were needed to maintain this cellular response, at least on a short time scale. $\mathrm{Ca}^{2+}$ transients were recorded in mouse and human stem cells (Ferreira-Martins et al., 2009; Kapur et al., 2007) and they were thought to be involved in cell growth. It was claimed that these $\mathrm{Ca}^{2+}$ transients did not require SOCE or plasma membrane $\mathrm{Ca}^{2+}$ ATPase (PMCA) but rely on $\mathrm{Ca}^{2+}$ cycling between ER and cytosol. Therefore, in the case of mammalian cells, calcium channels activation during cell cycle, hence in cell proliferation, remains to be clearly established (Capiod, 2011, 2013).

Evidence for an essential role of calcium channel expression in cell proliferation are numerous (Capiod, 2013). Its is interesting to note that sensitivity to external $\mathrm{Ca}^{2+}$ is rarely controlled as it seems obvious that calcium influx must be involved as it is the primary function for these proteins. But it is also known that some of these channels have additional functions and a few of them were named as chanzymes (Montell, 2003; Touyz, 2008). If a role for these proteins in cell proliferation independently of external $\mathrm{Ca}^{2+}$ remains to be proven, it is still interesting to reconsider the published data from a new perspective.

The role of calcium channels in immune cells proliferation will not be discussed here but it is indeed clear that these cells rely on calcium influx following T-cell receptor activation (Feske, 2011; Shaw and Feske, 2012). The present review is focused on the role of external $\mathrm{Ca}^{2+}$ concentration, calcium channel proteins and calcium influx in cell proliferation. The question here is to discuss how calcium channel protein can influence cell proliferation in the absence of external $\mathrm{Ca}^{2+}$, and when external $\mathrm{Ca}^{2+}$ is needed, to discriminate between calcium influx and CaSR activation.

\section{Evidence for a role for calcium influx in cell proliferation}

We have already discussed in recent reviews (Capiod, 2011, 2013) the need for external $\mathrm{Ca}^{2+}$ need in cell growth and division in mammalian cells. On one hand, several studies in the seventies and early eighties clearly demonstrated that sensitivity to external calcium depends on the degree of transformation with neoplastic cells being less dependent on external calcium (Boynton et al., 1976; Hazelton et al., 1979; Whitfield, 1992; Whitfield et al., 1979). On another hand, many other cell types required external $\mathrm{Ca}^{2+}$ to proliferate but it can then be questioned whether this divalent cation acts either through calcium fluxes or through the activation of calcium-sensing receptors.

Two main approaches were used to establish the role for calcium influx in cell proliferation. However, it seems that in several studies, the dependence on external $\mathrm{Ca}^{2+}$ in the presence of serum was not always assessed. This basic experience in the absence of external $\mathrm{Ca}^{2+}$ should have been conducted to demonstrate definitively the importance of calcium entry in the cell line of interest.

As described in a previous review (Capiod, 2013), several types of calcium channels seem to play a major role in cell proliferation and a non exhaustive list is shown on Fig. 1. Several other types of calcium channels also play a major role in the process of cell proliferation. For instances, purinergic P2X receptors (Burnstock, 2009; Burnstock and Kennedy, 2011), NMDA ionotropic receptors (Nacher and McEwen, 2006) and voltage-gated T type channels (Lory et al., 2006; Panner and Wurster, 2006), all subjects of recent reviews, are also involved in cell proliferation. Evidence for the involvement of cyclic nucleotide gated channels in cell proliferation is sparse but a recent paper suggested that blocking hyperpolarization-activated cyclic nucleotide-gated in embryonic stem cells resulted in an increase in $S$ phase and a decrease in $G_{0} / G_{1}$ phase of the cell cycle (Lau et al., 2011).

The use of calcium channels blockers was one of the strong arguments in favor of a role of calcium influx in cell proliferation. The blockade of L- and T-type voltage-dependent, SOCE or SICE channels have potential antiproliferative effects in several tissues. The list of blockers includes verapamil, diltiazem, nifedipine, amlodipine, mibefradil, TH-1177, 2-APB, SK\&F 96365 and carboxyamidotriazole (CAI) (Chung et al., 1994; Enfissi et al., 2004; Haverstick et al., 2000; Nel et al., 1986; Panner and Wurster, 2006; Taylor and Simpson, 1992; Taylor et al., 2008). Other $I_{\text {CRAC }}$ blockers have been identified and were the subject of another

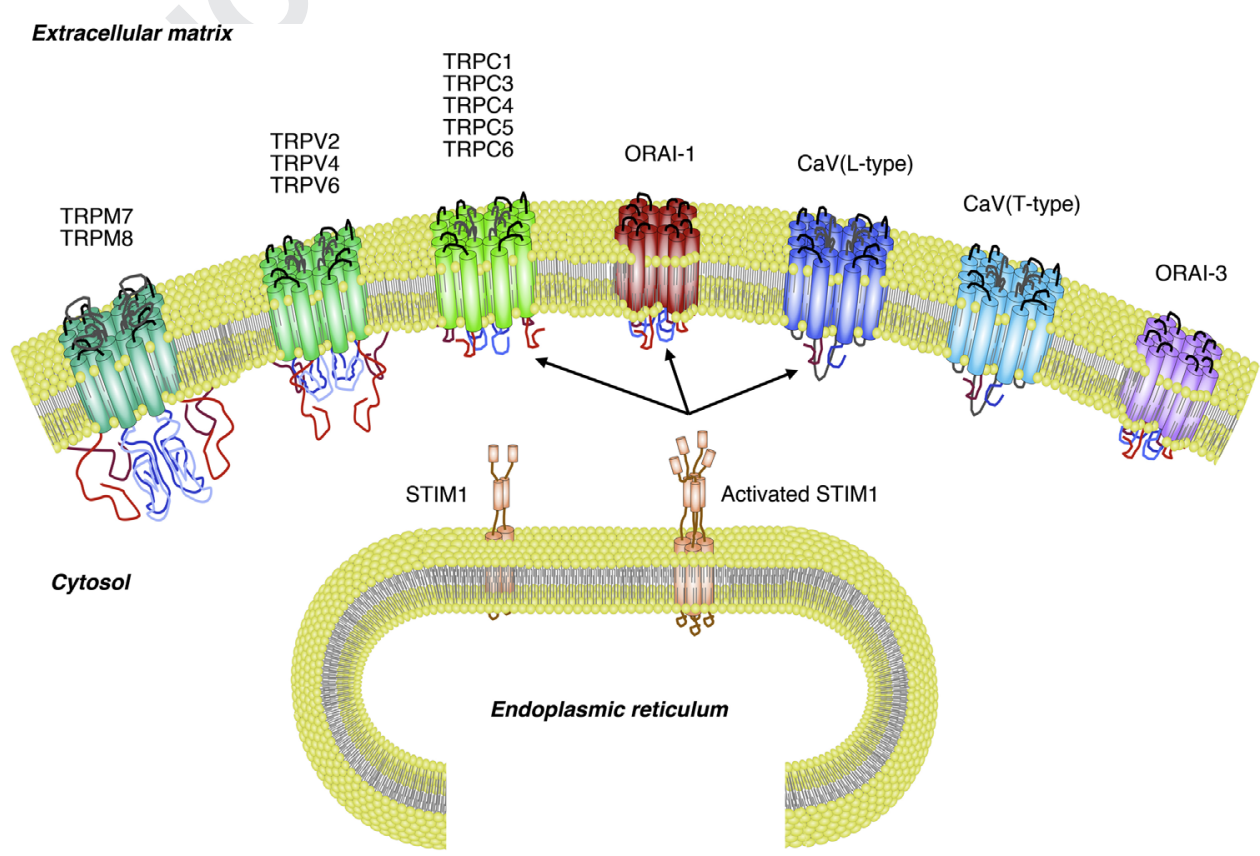

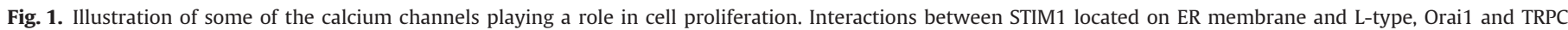
channels are indicated by the arrows. 
recent review (Parekh, 2010). Although none of these drugs are entirely selective to one type of channel, they all emphasize the role of calcium channels in the control of cell proliferation. A considerable effort is now made to discover selective activators and blockers of SOCE and SICE channels of use for therapeutic purposes as these channels play a major in the immune response and cancer development.

The link between calcium channel expression and cell proliferation was emphasized in knock-down experiments. In almost all cases, knocking down transient receptor potential canonical (TRPC), transient receptor potential vanilloid (TRPV), transient receptor potential melastatin (TRPM) or ORAI expression induces decrease in cell proliferation as well as calcium influx in almost all cases, strongly suggesting that reduced calcium entry and cell proliferation are directly linked (Capiod, 2013). However, there are a few exceptions to this above scheme. Reducing TRPC1 and TRPC4 expression decreased cell proliferation with no effect on SOCE or $I_{\text {CRAC }}$ activity in endothelial cells (Abdullaev et al., 2008). This is rather unexpected but provides evidence for additional functions for these proteins. TRPV4 behavior is rather different from other TRP channels. TRPV4 activation by synthetic phorbol-derivative, $4 \alpha$-phorbol 2,13-didecanoate ( $4 \alpha \mathrm{PDD})$, induced an increase in calcium influx and a decrease in proliferation of cholangiocyte in polycystic liver diseases (Gradilone et al., 2010) and human oesophageal epithelial cells (Ueda et al., 2011). The last two sets of data provide arguments against a role of calcium influx in cell proliferation in some particular cases. In addition, knocking down (stromal interacting molecule) STIM1, the ER membrane counterpart for SOCE channels (Cahalan, 2009; Varnai et al., 2009), has no effect on cell proliferation in vascular smooth muscle cells (Li et al., 2008), human myoblasts (Darbellay et al., 2009), HEK293 cells (El Boustany et al., 2010), human umbilical vein endothelial cells (HUVEC) derived cell line EA.hy926 (Antigny et al., 2012) and probably normal HUVEC (Abdullaev et al., 2008). At the same time $I_{\text {CRAC }}$ is greatly reduced, which suggested strongly that, in some cells, this current and cell proliferation can be uncoupled. Another exception to the direct relation between calcium influx and proliferation refers to the increase in psoriatic keratinocyte proliferation, coupled to a reduced TRPC6 expression (Leuner et al., 2011). Results with TRPM8 are controversial. TRPM8 is needed for pancreatic adenocarcinoma proliferation (Yee et al., 2010) but TRPM8 over-expression reduced human prostate PC-3 cells proliferation (Yang et al., 2009b).

There are less examples coupling calcium channel overexpression and cell proliferation. Overexpression of ORAI1 alone reduces amplitude of the native $\mathrm{I}_{\mathrm{CRAC}}$ (Peinelt et al., 2006; Soboloff et al., 2006) resulting in a clear and expected decrease in cell proliferation rate in A549 lung cancer cells (Hou et al., 2011). TRPC6overexpression by itself increased both SOCE amplitude and cell proliferation rate in human hepatoma cells (El Boustany et al., 2008).

\section{Calcium-sensing receptors}

The concentrations of $\left[\mathrm{Ca}^{2+}\right]_{\text {ext }}$ are kept at nearly constant levels with the help of a complex homeostatic system, which includes the parathyroid glands and calcitonin-secreting $C$ cells of the thyroid gland, kidneys, bones, and intestines (Brown and MacLeod, 2001). If $\mathrm{Ca}^{2+}$-selective ion channels enable $\mathrm{Ca}^{2+}$ to move across the cell membrane resulting in large and rapid increase in cytosolic calcium concentration, it was not clear how some cell types, such as the chief cells of the parathyroid glands, were extremely sensitive to the slightest variations in $\left[\mathrm{Ca}^{2+}\right]_{\text {ext. In }}$ 1993, a membrane-spanning, calcium-sensing receptor (CaSR) was cloned from the bovine parathyroid (Brown et al., 1993). This CaSR belongs to the GPCR family and mainly exists in the form of a dimer (Bai et al., 1998). Cloning of the receptor enabled to reveal that CaSR are expressed in a wide variety of tissues outside the parathyroid gland (Hofer et al., 2004) and it was suggested that CaSR serves as a sensor of local $\left[\mathrm{Ca}^{2+}\right]_{\text {ext }}$ in conditions in which this concentration is likely to fluctuate in situ. CaSR are not particularly sensitive to changes in $\left[\mathrm{Ca}^{2+}\right]_{\text {ext }}$ as half-maximal activation of the human parathyroid receptor does not occur until $\left[\mathrm{Ca}^{2+}\right]_{\text {ext }}$ reaches $3.5 \mathrm{mM}$ (Quinn et al., 1997). However, CaSR is stimulated over a wide range of $\mathrm{Ca}^{2+}$ concentrations (threshold around $0.5 \mathrm{mM} \mathrm{Ca}^{2+}$ with maximal stimulation at $5.5 \mathrm{mM}$ ), and the binding of $\mathrm{Ca}^{2+}$ to the CaSR is known to be a highly cooperative process (Hill coefficient $>3$ ), making CaSR a good $\left[\mathrm{Ca}^{2+}\right]$ increment detector. The receptor is therefore able to sense small $\left[\mathrm{Ca}^{2+}\right]_{\text {ext }}$ changes $( \pm 0.2 \mathrm{mM})$ in the physiological range (i.e. around $1.8 \mathrm{mM}$ ). Cancer, calcium and cell proliferation are intimately linked and it was obvious that CaSR would play a role here. CaSR increases cell proliferation in a number of cancer cell lines (Brown et al., 1998; Riccardi and Gamba, 1999; Rodland, 2004; Saidak et al., 2009; Sarkar and Kumar, 2012) including prostate (Lin et al., 1998) and breast cells (Cheng et al., 1998).

Another mean for CaSR to control cytosolic $\mathrm{Ca}^{2+}$ concentration and cell proliferation is to modify calcium channel expression. It was recently shown that CaSR proliferative effect in breast cancer cell line MCF-7 was due to an up regulation of TRPC1 (Transient Receptor Potential Canonical 1) through the ERK1/2 pathway in a large part (El Hiani et al., 2009a, 2009b). As mentioned before, CaSR are able to detect small changes in external calcium concentration which probably would not dramatically change calcium influx amplitude. SOCE and SICE activation and increase in calcium channel expression could relay and amplify CaSR effects on cell proliferation in several cell types.

Cell proliferation needs to be precisely controlled and should not, of course, start spontaneously whenever an increase of $\mathrm{Ca}^{2+}$ concentration is detected in plasma. Cancer cell proliferation is sensitive to external $\mathrm{Ca}^{2+}$ while normal cells stay quiescent. It was recently proposed that a switch of $G$ protein coupled to these CaSR could trigger cell proliferation in cancer cells (Mamillapalli et al., 2008). The CaSR expressed on normal mammary epithelial cells inhibited secretion of parathyroid hormone-related protein (PTHrP) and participate in the regulation of calcium and bone metabolism during lactation while in breast cancer cells, the CaSR was linked to PTHrP production enhancement. It was shown that CaSR are coupled to Goi in normal mammary epithelial cells but coupled to Gos in cancer cells and breast cancer cell line MCF-7 (Mamillapalli et al., 2008). Thus, the opposing effects of the CaSR on PTHrP production were because of alternate G-protein coupling of the receptor in normal versus transformed breast cells. Because PTHrP contributes to hypercalcemia and bone metastases, switching of G-protein usage by the CaSR may contribute to the pathogenesis of breast cancer. In this manner, PTHrP contributes to increased bone resorption and $\mathrm{Ca}^{2+}$ release during osteolysis. Elevated external $\mathrm{Ca}^{2+}$ concentration levels, at concentrations of 0.8 or $0.9 \mathrm{mM}$ higher than serum $\mathrm{Ca}^{2+}$ concentrations, activate the CaSR, producing additional release of PTHrP from the cancer cells, thus feeding the vicious cycle. This phenomenon occurs in several cancer cell lines including breast, prostate, rat testicular, astrocytomas, and meningiomas (Saidak et al., 2009). This important finding clearly demonstrated how external $\mathrm{Ca}^{2+}$ and CaSR can contribute to cancer development.

\section{Calcium channels and cell cycle distribution}

The need for calcium influx in cell proliferation implies that calcium channel expression is a key point in cell cycle progression. 


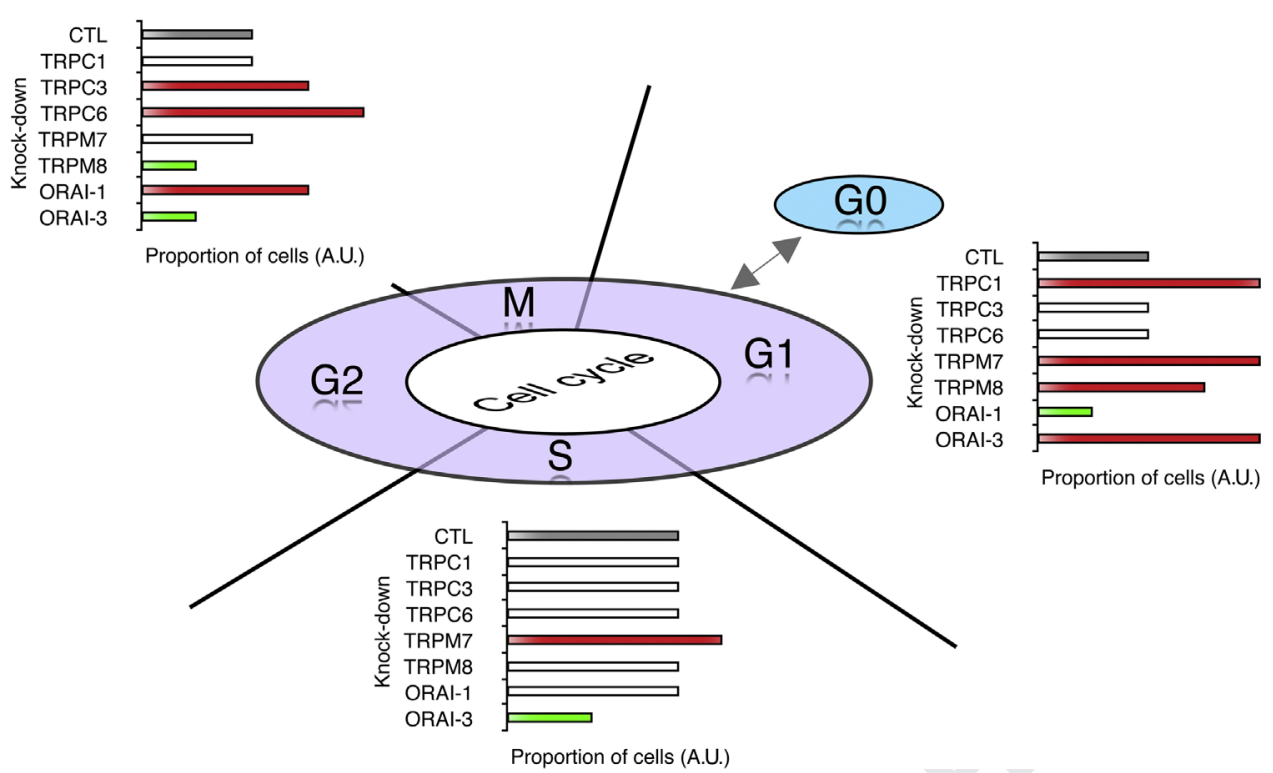

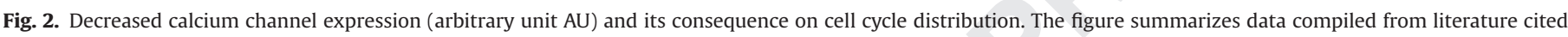
in the Text.

Recording of voltage-gated calcium channels along the cell cycle revealed large variations in L-type and T-type currents (Cribbs, 2006; Kuga et al., 1996) and similar behavior was later observed in SOCE activity (Bodding, 2001; Tani et al., 2007). It was then obvious that a decrease in calcium channel expression would lead to cell cycle arrest and Fig. 2 compiles the data obtained with TRP and ORAI channels (Abdullaev et al., 2008; Cai et al., 2009; Ding et al., 2010a, 2010b; El Boustany et al., 2010; Faouzi et al., 2011, 2013; Ge et al., 2009; Hanano et al., 2004; Hou et al., 2011; Kuang et al., 2011; Shi et al., 2009; Wang et al., 2010; Yang et al., 2009a, 2009b; Yee et al., 2010, 2011).

Knocking down calcium channel expression often has a more dramatic effect on cell proliferation inhibition than on cell cycle blockade. Decreasing ORAI1 and ORAI3 expression resulted in a clearer effect on cell proliferation than on cell cycle arrest. Cell proliferation was much slower, though not totally inhibited, in the absence of both calcium channels. The small but significant rise in cell number in $G_{2} / M$ phase of the cell cycle observed in the absence of ORAI1 and ORAI3 is probably underlying a bottleneck effect rather than a complete cell cycle arrest. It also suggested that the other cell cycle phases are probably equally affected by calcium channel extinction resulting in the same distribution using flow cytometry analysis.

The blockade in $\mathrm{G}_{2} / \mathrm{M}$ observed in ORAI1 and TRPC6 knockdowns is interesting as there is evidence that SOCE inactivates during mitosis ( $\mathrm{M}$ phase). The first suggestion that $\mathrm{Ca}^{2+}$ influx is inhibited during cell division was reported more than 20 years ago in a study of HeLa cells (Volpi and Berlin, 1988), probably through uncoupling of store depletion from SOCE (Preston et al., 1991). This was confirmed recently in HEK293, Cos-7, RBL-2H3 and HeLa cells where SOCE is dramatically reduced during mitosis (El Boustany et al., 2010; Russa et al., 2008; Smyth et al., 2009; Tani et al., 2007). STIM1 phosphorylation (Smyth et al., 2009), decrease in ORAI1 expression (El Boustany et al., 2010) and internalization of ORAI1 channel (Yu et al., 2009, 2010) during mitosis were recently suggested to be the reasons for the observed decrease in SOCE. The significance of this has already been discussed (Arredouani et al., 2010) and involves microtubule-network remodeling (Russa et al., 2008) as perturbation of the actin cytoskeleton resulted in a decrease in SOCE amplitude (Patterson et al., 1999).

\section{Additional functions for calcium channels and possible link to cell proliferation}

Recent work has demonstrated that many ion channels can directly influence biochemical events in ways that do not directly depend on their function as ion channels (Kaczmarek, 2006). As pointed out by Kaczmarek (2006), although many signaling molecules are known to associate with ion channels, the finding that an integral element of the channel also catalyzes an enzymatic reaction or participates in cell-cell interactions strongly suggests that changes in channel activity could influence these processes. Fragments or subunits of the voltage-gated $\mathrm{Ca}^{2+}$ channels probably provide additional functions by controlling $\mathrm{Ca}^{2+}$ homeostasis or gene regulation (Barbado et al., 2009; Rousset et al., 2005) or even acting as a transcription factor (Gomez-Ospina et al., 2006). Members of the TRPM subfamily have longer cytoplasmic C-terminal domains (Fig. 1) than other TRP channels and were the first ion channels shown to have enzymatic activity (Huang, 2004). As a result, members of this family were named 'chanzymes' (Montell, 2003). The C-terminus of TRPM2 encodes an ADP-ribose pyrophosphatase domain that binds ADP-ribose and NAD, both of which directly activate the channel (Sano et al., 2001; Zhang et al., 2006). TRPM6 and TRPM7 both contain protein kinases in their C-terminal domains (Schmitz et al., 2005). These kinases are capable of phosphorylating both the channels themselves and other substrates. It is therefore conceivable that new functions for TRPC and ORAI channels could be uncovered in near future and that a direct link between the channel structure and the transcriptional machinery would explain why some cells need the channel more than calcium influx to proliferate. TRPV1 can be directly phosphorylated by CdK5 and inhibition of CdK5 activity by roscovitine decreases TRPV1 function and $\mathrm{Ca}^{2+}$ influx (Pareek et al., 2007) or L-type $\mathrm{Ca}_{\mathrm{v}} 1.2$ activity (Yarotskyy and Elmslie, 2007). As a matter of fact, our preliminary results (Borowiec et al., unpublished data) show that HEK293 cell proliferation strictly Q2 depends on ORAI1 and ORAI3 expression and is totally independent of external calcium. The mechanisms by which these channels can control cell cycle and division are still unknown. But it is clear that they can interact with more than one single intracellular protein and we are currently investigating which domain of these 


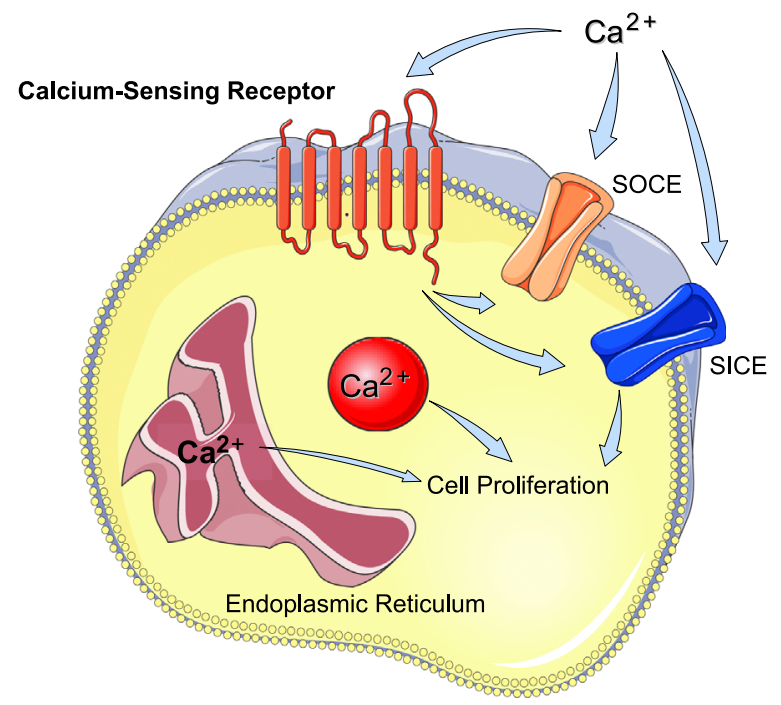

Fig. 3. Balance between calcium-sensing receptors, $E R \mathrm{Ca}^{2+}$ contents and calcium influx in the control of cell proliferation. CaSR and calcium channels External calcium induced cellular responses are relayed by CaSR or calcium channels. Calcium influx can activate intracellular kinases and phosphatases directly linked to cell proliferation. CaSR-induced cell proliferation involves second messengers such as 1,4,5 trisphosphate or diacylglycerol, direct activation of SOCE and SICE channels, increase in calcium channel expression at the plasma membrane and release from ER. Intraluminal $\mathrm{Ca}^{2+}$ concentration plays a major in controlling cell proliferation rate. Calcium influx is important in maintaining intraluminal $\mathrm{Ca}^{2+}$ concentration on the long term and during stimulation of the cells by extracellular agonists including growth factors.

channel-proteins is essential for this unexpected physiological response.

\section{Conclusion and perspectives}

We previously discussed the role of ER $\mathrm{Ca}^{2+}$ contents in cell proliferation (Capiod, 2013). Intraluminal $\mathrm{Ca}^{2+}$ concentration eventually decreases during repeated stimulation by extracellular agonists, including growth factors involved in cell proliferation. Fig. 3 illustrates external $\mathrm{Ca}^{2+}$ contribution to CaSR activity, activated calcium influx and sustained intraluminal $\mathrm{Ca}^{2+}$ concentration. It emphasizes the relative balance of CaSR, calcium channels and $\mathrm{ER} \mathrm{Ca}^{2+}$ in controlling cell proliferation and cancer cell development.

To conclude, the relationship between calcium influx and cell proliferation should not be taken for granted in all cell types and in all physiological conditions. A better knowledge of the real nature of the calcium channels involved in each cell type should provide information on how calcium entry should control all the downstream events leading to cell proliferation. Establishing new functions for calcium channel in cell proliferation independently of calcium flux, looking for specific blockers and studying the calcium influx during cell cycle in the absence of any kind of chemically-induced block, are probably the next steps needed to clarify the role of calcium influx in cell proliferation and cell cycle progression.

\section{References}

Abdullaev, I.F., Bisaillon, J.M., Potier, M., Gonzalez, J.C., Motiani, R.K., Trebak, M. 2008. Stim 1 and Orai1 mediate CRAC currents and store-operated calcium entry important for endothelial cell proliferation. Circ. Res. 103, 1289-1299.

Antigny, F., Girardin, N., Frieden, M., 2012. Transient receptor potential canonical channels are required for in vitro endothelial tube formation. J. Biol. Chem. 287, 5917-5927.
Arredouani, A., Yu, F., Sun, L., Machaca, K., 2010. Regulation of store-operated $\mathrm{Ca}^{2+}$ entry during the cell cycle. J. Cell Sci. 123, 2155-2162.

Bai, M., Trivedi, S., Brown, E.M., 1998. Dimerization of the extracellular calciumsensing receptor (CaR) on the cell surface of CaR-transfected HEK293 cells. J. Biol. Chem. 273, 23605-23610.

Barbado, M., Fablet, K., Ronjat, M., De Waard, M., 2009. Gene regulation by voltagedependent calcium channels. BBA 1793, 1096-1104.

Bodding, M., 2001. Reduced store-operated $\mathrm{Ca}(2+)$ currents in rat basophilic leukaemia cells cultured under serum-free conditions. Cell Calcium 30, 141-150.

Boynton, A.L., Whitfield, J.F., Isaacs, R.J., 1976. The different roles of serum and calcium in the control of proliferation of BALB/c $3 T 3$ mouse cells. In Vitro 12, 120-123.

Breitwieser, G.E., Gama, L., 2001. Calcium-sensing receptor activation induces intracellular calcium oscillations. Am. J. Physiol. 280, C1412-C1421.

Brown, E.M., Gamba, G., Riccardi, D., Lombardi, M., Butters, R., Kifor, O., Sun, A., Hediger, M.A., Lytton, J., Hebert, S.C., 1993. Cloning and characterization of an extracellular $\mathrm{Ca}(2+)$-sensing receptor from bovine parathyroid. Nature 366, 575-580.

Brown, E.M., MacLeod, R.J., 2001. Extracellular calcium sensing and extracellular calcium signaling. Physiol. Rev. 81, 239-297.

Brown, E.M., Pollak, M., Hebert, S.C., 1998. The extracellular calcium-sensing receptor: its role in health and disease. Annu. Rev. Med. 49, 15-29.

Burnstock, G., 2009. Purinergic signalling: past, present and future. Braz. J. Med. Biol. Res.. (=Revista brasileira de pesquisas medicas e biologicas/Sociedade Brasileira de Biofisica... [et al. 42, 3-8).

Burnstock, G., Kennedy, C., 2011. P2X receptors in health and disease. Adv. Pharmacol. (San Diego, Calif 61, 333-372.

Cahalan, M.D., 2009. STIMulating store-operated $\mathrm{Ca}(2+)$ entry. Nat. Cell Biol. 11, 669-677.

Cai, R., Ding, X., Zhou, K., Shi, Y., Ge, R., Ren, G., Jin, Y., Wang, Y., 2009. Blockade of TRPC6 channels induced G2/M phase arrest and suppressed growth in human gastric cancer cells. Int. J. Cancer 125, 2281-2287.

Capiod, T., 2011. Cell proliferation, calcium influx and calcium channels. Biochimie 93, 2075-2079.

Capiod, T., 2013. The need for calcium channels in cell proliferation. Recent Pat Anticancer Drug Discov. 8, 4-17.

Cheng, I., Klingensmith, M.E., Chattopadhyay, N., Kifor, O., Butters, R.R., Soybel, D.I., Brown, E.M., 1998. Identification and localization of the extracellular calciumsensing receptor in human breast. J. Clin. Endocrinol. Metab. 83, 703-707.

Chung, S.C., McDonald, T.V., Gardner, P., 1994. Inhibition by SK\&F 96365 of $\mathrm{Ca}^{2+}$ current, IL-2 production and activation in T lymphocytes. Br. J. Pharmacol. 113, 861-868.

Cribbs, L.L., 2006. T-type $\mathrm{Ca}^{2+}$ channels in vascular smooth muscle: multiple functions. Cell Calcium 40, 221-230.

Darbellay, B., Arnaudeau, S., Konig, S., Jousset, H., Bader, C., Demaurex, N., Bernheim, L., 2009. STIM1- and Orai1-dependent store-operated calcium entry regulates human myoblast differentiation. J. Biol. Chem. 284, 5370-5380.

Ding, X., He, Z., Shi, Y., Wang, Q., Wang, Y., 2010a. Targeting TRPC6 channels in oesophageal carcinoma growth. Expert Opin. Ther. Targets 14, 513-527.

Ding, X., He, Z., Zhou, K., Cheng, J., Yao, H., Lu, D., Cai, R., Jin, Y., Dong, B., Xu, Y., Wang, Y., 2010b. Essential role of TRPC6 channels in G2/M phase transition and development of human glioma. J. Nat. Cancer Inst. 102, 1052-1068.

El Boustany, C., Bidaux, G., Enfissi, A., Delcourt, P., Prevarskaya, N., Capiod, T., 2008. Capacitative calcium entry and transient receptor potential canonical 6 expression control human hepatoma cell proliferation. Hepatology 47, 2068-2077.

El Boustany, C., Katsogiannou, M., Delcourt, P., Dewailly, E., Prevarskaya, N., Borowiec, A.S., Capiod, T., 2010. Differential roles of STIM1, STIM2 and Orai1 in the control of cell proliferation and SOCE amplitude in HEK293 cells. Cell Calcium 47, 350-359.

El Hiani, Y., Ahidouch, A., Lehen'kyi, V., Hague, F., Gouilleux, F., Mentaverri, R. Kamel, S., Lassoued, K., Brule, G., Ouadid-Ahidouch, H., 2009a. Extracellular signal-regulated kinases 1 and 2 and TRPC1 channels are required for calciumsensing receptor-stimulated MCF-7 breast cancer cell proliferation. Cell Physiol. Biochem. 23, 335-346.

El Hiani, Y., Lehen'kyi, V., Ouadid-Ahidouch, H., Ahidouch, A., 2009b. Activation of the calcium-sensing receptor by high calcium induced breast cancer cell proliferation and TRPC1 cation channel over-expression potentially through EGFR pathways. Arch Biochem. Biophys. 486, 58-63.

Enfissi, A., Prigent, S., Colosetti, P., Capiod, T., 2004. The blocking of capacitative calcium entry by 2-aminoethyl diphenylborate (2-APB) and carboxyamidotriazole (CAI) inhibits proliferation in Hep G2 and Huh-7 human hepatoma cells. Cell Calcium 36, 459-467.

Faouzi, M., Hague, F., Potier, M., Ahidouch, A., Sevestre, H., Ouadid-Ahidouch, H., 2011. Down-regulation of Orai3 arrests cell-cycle progression and induces apoptosis in breast cancer cells but not in normal breast epithelial cells. J. Cell Physiol. 226, 542-551.

Faouzi, M., Kischel, P., Hague, F., Ahidouch, A., Benzerdjeb, N., Sevestre, H., Penner, R., Ouadid-Ahidouch, H., 2013. ORAI3 silencing alters cell proliferation and cell cycle progression via c-myc pathway in breast cancer cells. BBA 1833, 752-760.

Ferreira-Martins, J., Rondon-Clavo, C., Tugal, D., Korn, J.A., Rizzi, R., Padin-Iruegas, M.E., Ottolenghi, S., De Angelis, A., Urbanek, K., Ide-Iwata, N., D’Amario, D., Hosoda, T., Leri, A., Kajstura, J., Anversa, P., Rota, M., 2009. Spontaneous calcium oscillations regulate human cardiac progenitor cell growth. Circ. Res. 105, 764-774. 
Feske, S., 2011. Immunodeficiency due to defects in store-operated calcium entry. Ann. N.Y. Acad. Sci. 1238, 74-90.

Ge, R., Tai, Y., Sun, Y., Zhou, K., Yang, S., Cheng, T., Zou, Q., Shen, F., Wang, Y., 2009. Critical role of TRPC6 channels in VEGF-mediated angiogenesis. Cancer Lett. 283, 43-51.

Gomez-Ospina, N., Tsuruta, F., Barreto-Chang, O., Hu, L., Dolmetsch, R., 2006. The C terminus of the L-type voltage-gated calcium channel $\mathrm{Ca}(\mathrm{V}) 1.2$ encodes a transcription factor. Cell 127, 591-606.

Gradilone, S.A., Masyuk, T.V., Huang, B.O., Banales, J.M., Lehmann, G.L., Radtke, B.N., Stroope, A., Masyuk, A.I., Splinter, P.L., LaRusso, N.F., 2010. Activation of Trpv4 reduces the hyperproliferative phenotype of cystic cholangiocytes from an animal model of ARPKD. Gastroenterology 139 (304-314), e302.

Hanano, T., Hara, Y., Shi, J., Morita, H., Umebayashi, C., Mori, E., Sumimoto, H., Ito, Y., Mori, Y., Inoue, R., 2004. Involvement of TRPM7 in cell growth as a spontaneously activated $\mathrm{Ca}^{2+}$ entry pathway in human retinoblastoma cells. J. Pharmacol. Sci. 95, 403-419.

Haverstick, D.M., Heady, T.N., Macdonald, T.L., Gray, L.S., 2000. Inhibition of human prostate cancer proliferation in vitro and in a mouse model by a compound synthesized to block $\mathrm{Ca}^{2+}$ entry. Cancer Res. 60, 1002-1008.

Hazelton, B., Mitchell, B., Tupper, J., 1979. Calcium, magnesium, and growth control in the WI-38 human fibroblast cell. J. Cell Biol. 83, 487-498.

Hofer, A.M., Gerbino, A., Caroppo, R., Curci, S., 2004. The extracellular calciumsensing receptor and cell-cell signaling in epithelia. Cell Calcium 35, 297-306.

Hou, M.F., Kuo, H.C., Li, J.H., Wang, Y.S., Chang, C.C., Chen, K.C., Chen, W.C., Chiu, C.C., Yang, S., Chang, W.C., 2011. Orai1/CRACM1 overexpression suppresses cell proliferation via attenuation of the store-operated calcium influx-mediated signalling pathway in A549 lung cancer cells. BBA 1810, 1278-1284.

Huang, C.L., 2004. The transient receptor potential superfamily of ion channels. J. Am. Soc. Nephrol. 15, 1690-1699.

Kaczmarek, L.K., 2006. Non-conducting functions of voltage-gated ion channels. Nat. Rev. Neurosci. 7, 761-771.

Kapur, N., Mignery, G.A., Banach, K., 2007. Cell cycle-dependent calcium oscillations in mouse embryonic stem cells. Am. J. Physiol. 292, C1510-1518.

Kuang, C.Y., Yu, Y., Wang, K., Qian, D.H., Den, M.Y., Huang, L., 2011. Knockdown of transient receptor potential canonical-1 reduces the proliferation and migration of endothelial progenitor cells. Stem Cells Dev..

Kuga, T., Kobayashi, S., Hirakawa, Y., Kanaide, H., Takeshita, A., 1996. Cell cycledependent expression of $\mathrm{L}$ - and T-type $\mathrm{Ca}^{2+}$ currents in rat aortic smooth muscle cells in primary culture. Circ. Res. 79, 14-19.

Lau, Y.T., Wong, C.K., Luo, J., Leung, L.H., Tsang, P.F., Bian, Z.X., Tsang, S.Y., 2011. Effects of hyperpolarization-activated cyclic nucleotide-gated (HCN) channel blockers on the proliferation and cell cycle progression of embryonic stem cells. Pflugers Arch. 461, 191-202.

Leuner, K., Kraus, M., Woelfle, U., Beschmann, H., Harteneck, C., Boehncke, W.H., Schempp, C.M., Muller, W.E., 2011. Reduced TRPC channel expression in psoriatic keratinocytes is associated with impaired differentiation and enhanced proliferation. PLoS One 6, e14716.

Li, J., Sukumar, P., Milligan, C.J., Kumar, B., Ma, Z.Y., Munsch, C.M., Jiang, L.H., Porter, K.E., Beech, D.J., 2008. Interactions, functions, and independence of plasma membrane STIM1 and TRPC1 in vascular smooth muscle cells. Circ. Res. 103, e97-104.

Lin, K.I., Chattopadhyay, N., Bai, M., Alvarez, R., Dang, C.V., Baraban, J.M., Brown, E. M., Ratan, R.R., 1998. Elevated extracellular calcium can prevent apoptosis via the calcium-sensing receptor. Biochem. Biophys. Res. Commun. 249, 325-331.

Lory, P., Bidaud, I., Chemin, J., 2006. T-type calcium channels in differentiation and proliferation. Cell Calcium 40, 135-146.

Mamillapalli, R., VanHouten, J., Zawalich, W., Wysolmerski, J., 2008. Switching of G-protein usage by the calcium-sensing receptor reverses its effect on parathyroid hormone-related protein secretion in normal versus malignant breast cells. J. Biol. Chem. 283, 24435-24447.

Montell, C., 2003. $\mathrm{Mg}^{2+}$ homeostasis: the $\mathrm{Mg}^{2+}$ nificent TRPM chanzymes. Curr. Biol. 13, R799-801.

Nacher, J., McEwen, B.S., 2006. The role of $N$-methyl-D-asparate receptors in neurogenesis. Hippocampus 16, 267-270.

Nel, A.E., Dirienzo, W., Stefanini, G.F., Wooten, M.W., Canonica, G.W., Lattanze, G.R., Stevenson, H.C., Miller, P., Fudenberg, H.H., Galbraith, R.M., 1986. Inhibition of T3 mediated T-cell proliferation by $\mathrm{Ca}^{2+}$-channel blockers and inhibitors of $\mathrm{Ca}^{2+} /$ phospholipid-dependent kinase. Scand. J. Immunol. 24, 283-290.

Panner, A., Wurster, R.D., 2006. T-type calcium channels and tumor proliferation. Cell Calcium 40, 253-259.

Pareek, T.K., Keller, J., Kesavapany, S., Agarwal, N., Kuner, R., Pant, H.C., Iadarola, M.J., Brady, R.O., Kulkarni, A.B., 2007. Cyclin-dependent kinase 5 modulates nociceptive signaling through direct phosphorylation of transient receptor potential vanilloid 1. Proc. Nat. Acad. Sci. U.S.A. 104, 660-665.

Parekh, A.B., 2010. Store-operated CRAC channels: function in health and disease. Nat. Rev. 9, 399-410.

Patterson, R.L., van Rossum, D.B., Gill, D.L., 1999. Store-operated Ca ${ }^{2+}$ entry: evidence for a secretion-like coupling model. Cell 98, 487-499.

Peinelt, C., Vig, M., Koomoa, D.L., Beck, A., Nadler, M.J., Koblan-Huberson, M., Lis, A., Fleig, A., Penner, R., Kinet, J.P., 2006. Amplification of CRAC current by STIM1 and CRACM1 (Orai1). Nat. Cell Biol. 8, 771-773.

Preston, S.F., Sha'afi, R.I., Berlin, R.D., 1991. Regulation of $\mathrm{Ca}^{2+}$ influx during mitosis: $\mathrm{Ca}^{2+}$ influx and depletion of intracellular $\mathrm{Ca}^{2+}$ stores are coupled in interphase but not mitosis. Cell Regul. 2, 915-925.

Putney, J.W., Bird, G.S., 2008. Cytoplasmic calcium oscillations and store-operated calcium influx. J. Physiol. 586, 3055-3059.
Quinn, S.J., Ye, C.P., Diaz, R., Kifor, O., Bai, M., Vassilev, P., Brown, E., 1997. The $\mathrm{Ca}^{2+}$ sensing receptor: a target for polyamines. Am. J. Physiol. 273, C1315-1323.

Rey, O., Young, S.H., Jacamo, R., Moyer, M.P., Rozengurt, E., 2010. Extracellular calcium sensing receptor stimulation in human colonic epithelial cells induces intracellular calcium oscillations and proliferation inhibition. J. Cell. Physiol. 225, 73-83.

Riccardi, D., Gamba, G., 1999. The many roles of the calcium-sensing receptor in health and disease. Arch. Med. Res. 30, 436-448.

Rodland, K.D., 2004. The role of the calcium-sensing receptor in cancer. Cell Calcium 35, 291-295.

Rousset, M., Cens, T., Charnet, P., 2005. Alone at last! New functions for $\mathrm{Ca}^{2+}$ channel beta subunits? Sci. STKE 2005, pe11.

Russa, A.D., Ishikita, N., Masu, K., Akutsu, H., Saino, T., Satoh, Y., 2008. Microtubule remodeling mediates the inhibition of store-operated calcium entry (SOCE) during mitosis in COS-7 cells. Arch. Histol. Cytol. 71, 249-263.

Saidak, Z., Mentaverri, R., Brown, E.M., 2009. The role of the calcium-sensing receptor in the development and progression of cancer. Endocr. Rev. 30, 178-195.

Sano, Y., Inamura, K., Miyake, A., Mochizuki, S., Yokoi, H., Matsushime, H., Furuichi, K., 2001. Immunocyte $\mathrm{Ca}^{2+}$ influx system mediated by LTRPC2. Science (New York, N.Y 293, 1327-1330.

Sarkar, P., Kumar, S., 2012. Calcium sensing receptor modulation for cancer therapy. Asian Pac. J. Cancer Prev. 13, 3561-3568.

Schmitz, C., Dorovkov, M.V., Zhao, X., Davenport, B.J., Ryazanov, A.G., Perraud, A.L., 2005. The channel kinases TRPM6 and TRPM7 are functionally nonredundant. J. Biol. Chem. 280, 37763-37771.

Shaw, P.J., Feske, S., 2012. Physiological and pathophysiological functions of SOCE in the immune system. Front. Biosci. (Elite edition) 4, 2253-2268.

Shi, Y., Ding, X., He, Z.H., Zhou, K.C., Wang, Q., Wang, Y.Z., 2009. Critical role of TRPC6 channels in G2 phase transition and the development of human oesophageal cancer. Gut 58, 1443-1450.

Shuttleworth, T.J., Mignen, O., 2003. Calcium entry and the control of calcium oscillations. Biochem. Soc. Trans. 31, 916-919.

Smyth, J.T., Petranka, J.G., Boyles, R.R., DeHaven, W.I., Fukushima, M., Johnson, K.L., Williams, J.G., Putney Jr., J.W., 2009. Phosphorylation of STIM1 underlies suppression of store-operated calcium entry during mitosis. Nat. Cell Biol. 11, 1465-1472.

Soboloff, J., Spassova, M.A., Tang, X.D., Hewavitharana, T., Xu, W., Gill, D.L., 2006. Orai1 and STIM reconstitute store-operated calcium channel function. J. Biol. Chem. 281, 20661-20665.

Tani, D., Monteilh-Zoller, M.K., Fleig, A., Penner, R., 2007. Cell cycle-dependent regulation of store-operated $\mathrm{I}(\mathrm{CRAC})$ and $\mathrm{Mg}^{2+}$-nucleotide-regulated MagNuM (TRPM7) currents. Cell Calcium 41, 249-260.

Taylor, J.M., Simpson, R.U., 1992. Inhibition of cancer cell growth by calcium channel antagonists in the athymic mouse. Cancer Res. 52, 2413-2418.

Taylor, J.T., Huang, L., Pottle, J.E., Liu, K., Yang, Y., Zeng, X., Keyser, B.M., Agrawal, K.C., Hansen, J.B., Li, M., 2008. Selective blockade of T-type $\mathrm{Ca}^{2+}$ channels suppresses human breast cancer cell proliferation. Cancer Lett. 267, 116-124.

Thompson, J.L., Shuttleworth, T.J., 2011. Orai channel-dependent activation of phospholipase C-delta: a novel mechanism for the effects of calcium entry on calcium oscillations. J. Physiol. 589, 5057-5069.

Touyz, R.M., 2008. Transient receptor potential melastatin 6 and 7 channels, magnesium transport, and vascular biology: implications in hypertension. Am. J. Physiol. Heart Circ. Physiol. 294, H1103-1118.

Ueda, T., Shikano, M., Kamiya, T., Joh, T., Ugawa, S., 2011. The TRPV4 channel is a novel regulator of intracellular $\mathrm{Ca}^{2+}$ in human esophageal epithelial cells. Am. J. Physiol. 301, G138-147.

Varnai, P., Hunyady, L., Balla, T., 2009. STIM and Orai: the long-awaited constituents of store-operated calcium entry. Trends Pharmacol. Sci. 30, 118-128.

Volpi, M., Berlin, R.D., 1988. Intracellular elevations of free calcium induced by activation of histamine $\mathrm{H} 1$ receptors in interphase and mitotic HeLa cells: hormone signal transduction is altered during mitosis. J. Cell Biol. 107, 2533-2539.

Wang, Y., Yue, D., Li, K., Liu, Y.L., Ren, C.S., Wang, P., 2010. The role of TRPC6 in HGFinduced cell proliferation of human prostate cancer DU145 and PC3 cells. Asian J. Androl. 12, 841-852.

Wedel, B., Boyles, R.R., Putney Jr., J.W., Bird, G.S., 2007. Role of the store-operated calcium entry proteins Stim1 and Orai1 in muscarinic cholinergic receptorstimulated calcium oscillations in human embryonic kidney cells. J. Physiol. 579, 679-689.

Whitfield, J.F., 1992. Calcium signals and cancer. Crit. Rev. Oncog. 3, 55-90.

Whitfield, J.F., Boynton, A.L., MacManus, J.P., Sikorska, M., Tsang, B.K., 1979. The regulation of cell proliferation by calcium and cyclic AMP. Mol. Cell Biochem. 27, 155-179.

Yang, S.L., Cao, Q., Zhou, K.C., Feng, Y.J., Wang, Y.Z., 2009a. Transient receptor potential channel $\mathrm{C} 3$ contributes to the progression of human ovarian cancer. Oncogene 28, 1320-1328.

Yang, Z.H., Wang, X.H., Wang, H.P., Hu, L.Q., 2009b. Effects of TRPM8 on the proliferation and motility of prostate cancer PC-3 cells. Asian J. Androl. 11, 157-165.

Yarotskyy, V., Elmslie, K.S., 2007. Roscovitine, a cyclin-dependent kinase inhibitor, affects several gating mechanisms to inhibit cardiac L-type $(\mathrm{Ca}(\mathrm{V}) 1.2)$ calcium channels. Br. J. Pharmacol. 152, 386-395.

Yee, N.S., Zhou, W., Lee, M., 2010. Transient receptor potential channel TRPM8 is over-expressed and required for cellular proliferation in pancreatic adenocarcinoma. Cancer Lett. 297, 49-55. 
Yee, N.S., Zhou, W., Liang, I.C., 2011. Transient receptor potential ion channel Trpm7 regulates exocrine pancreatic epithelial proliferation by $\mathrm{Mg}^{2+}$-sensitive Socs3a signaling in development and cancer. Dis. Model Mech. 4, 240-254.

Yu, F., Sun, L., Machaca, K., 2009. Orai1 internalization and STIM1 clustering inhibition modulate SOCE inactivation during meiosis. Proc. Nat. Acad. Sci. U. S.A. $106,17401-17406$
Yu, F., Sun, L., Machaca, K., 2010. Constitutive recycling of the store-operated $\mathrm{Ca}^{2+}$ channel Orai1 and its internalization during meiosis. J. Cell Biol. 191, 523-535.

Zhang, W., Hirschler-Laszkiewicz, I., Tong, Q., Conrad, K., Sun, S.C., Penn, L., Barber, D.L., Stahl, R., Carey, D.J., Cheung, J.Y., Miller, B.A., 2006. TRPM2 is an ion channel that modulates hematopoietic cell death through activation of caspases and PARP cleavage. Am. J. Physiol. 290, C1146-1159. 